\title{
EMBODIMENT OF RESPONSIBILITY TO FULFILL HUMAN RIGHTS THROUGH HUMAN RIGHTS DUE DILIGENCE BY CORPORATIONS IN INDONESIA
}

\author{
Ika Khairunnisa Simanjuntak \\ S.H, University of Indonesia, Indonesia, ikakhairunnisa@rocketmail.com
}

\begin{abstract}
Corporations occupy the highest position as perpetrators of human rights violations and environmental destruction in the last three years. Moreover according to data released by the National Commission on Human Rights, at the beginning of 2017 corporations ranks second most publicly reported institutions. One of the causes of human rights violations committed by corporations is the absence of binding standards and guidelines as direction in conducting business activities. Responding to this problem the government issued a National Action Plan on Business and Human Rights whose contents are obliging the company to perform Human Right Due Diligence in its business activities. The presence of the concept of Human Rights Due Diligence cannot be separated from various debates. Human rights advocacy groups strongly support it but on the other hand, business groups are strongly opposed to its existence because the company is considered not responsible for the fulfillment of human rights. This paper uses normative methodology by examining the library materials or secondary data as the main object. The problems discussed in this study are: First, how is the development of responsibility for the fulfillment of human rights by corporations in Indonesia? Second, how is the urgency of implementing Human Right Due Diligence by corporations in Indonesia? Based on the problem, this study aims to review the conception of human rights and analyze its development in the context of theory and law on efforts to fulfill human rights by corporations in Indonesia. It also aims to analyze the causes of implementation and examples of the Human Right Due Diligence regulation so that it is known urgency of implementation for the corporation as an effort to fulfill human rights in Indonesia.
\end{abstract}

Keywords: Fulfilling Human Rights, Corporations, Human Right Due Diligence.

\section{INTRODUCTION}

\subsection{Background}

The state has a central role in protecting human rights. Despite the belief that the state is the most potent actor of violation of human rights, this obligation is also based on the recognition of human individuals as the 
subject of international law, ${ }^{1}$ so that the state is required to provide protection, promotion and respect for human rights especially for its citizens. This then became a worldwide concern and was the concept of the modern world after the Second World War. ${ }^{2}$ On this basis, Indonesia is present as a single actor fulfillment of human rights of all Indonesian people through various legal instruments both superstructure and infrastructure.

In principle the 2nd Pancasila mandated "Just and Civilized Humanity" which became the basic value of recognition of human rights that human beings should be treated equally with dignity and existence. This base value is embodied into various laws such as the Constitution of Indonesian Article 29 A up to 29J, Law No. 39 of 1999 on Human Rights ${ }^{3}$ and Law No. 26 of 2000 on the human rights courts and legal institutions such as the National Human Rights Commission, the Ombudsman, and the National Commission for Women and etc. All of them have explicitly demonstrated that the State of Indonesia is committed to fulfilling, protecting and respecting human rights, which is compatible with the Universal Declaration of Human Rights $(\mathrm{UDHR})^{4}$ and various international human rights instruments ratified by Indonesia, such as the International Covenant on Civil and Political Rights and the International Covenant on Economic, Social and Cultural Rights.

The globalization of economic activity today is getting worse with the liberalization of trade and the expansion of market impacts that put corporations as non-state actors who have great potential to be human rights violators. This fact has changed the paradigm that corporations that initially have no responsibility for the fulfillment of human rights, in fact become major offenders. Indonesian Commission for Victims of Violence said that in 2016 there have been 149 human rights violations caused by business activities in Indonesia such as deprivation of community land rights, pollution and environmental destruction and mining exploitation. ${ }^{5}$ The latest data from Kontras is reinforced by previous data from institutions such as Indonesian Human Right Counsel, Indonesian Environment Forum and Indonesian Institute for Community Studies and Advocacy which concluded that corporations occupies the highest numbers as perpetrators of human rights violation. ${ }^{6}$ The fact is not equipped with policies and regulations related to corporate responsibility to human rights. The presence of Corporate Social Responsibility is not effective enough and is not binding in the fulfillment of human rights for Indonesian people. In addition, the difficulty to prosecute the corporation and determine its liability at the court level led to no solution to this problem. ${ }^{7}$

In response to this United Nations began to pay attention to the business sector. ${ }^{8}$ It is recognized that one of the causes of human rights violations committed by corporations is the absence of binding standards and guidelines that can guide corporate business activities without violating the law and human rights principles. In July 2005, UN General Secretary, Kofi Annan appointed John Ruggie, a Harvard professor as "UN Secretary-General's Special Representative for Human Rights and Transnational Companies and Other Businesses" to investigate business and human rights. John Ruggie then passed the Guiding Principles for Business and Human Rights: Implementing the UN Framework "Protection, Respect and Recovery". The principles in this guide state that corporations should respect and internationally recognized human rights, even if human rights are not recognized in its national legal system. These principles mandates every corporation to conduct human rights due diligence as a compliance with the guiding principles. ${ }^{9}$

Indonesia with the vision of making human rights an integral part of conducting business activities, also contributes to the Guiding Principles for Business and Human Rights as a guideline so that every business activity in Indonesia is formed to implement a due diligence mechanism called Human Right Due Diligence. Application of the principles outlined in the National Action Plan on Business and Human Rights which Indonesia was the first country in Southeast Asia that has had the National Action Plan.

\subsection{Research Methods}

This research was conducted using juridical-normative approach method. The normative juridical approach

\footnotetext{
${ }^{1}$ Wiliam R. Slomanson, Fundamental Perspectives on International Law, (Belmont : Wadsworth, 2000), p.173.

${ }^{2}$ Saafroedin Bahar, Konteks Kenegaraan Hak Asasi Manusia, (Jakarta : Pustaka Sinar Harapan, 2002), p. 357.

${ }^{3}$ Republic of Indonesia, Article 1 No. 1 Law No. 39 of 1999 on Human Rights.

${ }^{4}$ Rights Resources Initiative, Ruang-Ruang Advokasi Kasus Penghormatan Hak Asasi Manusia oleh Perusahaan, (Batam: ASM Law Office, 2015). Stipulated by the General Assembly in resolution 217 A (III) of 10 December 1948.

${ }^{5}$ Ahmad Sofian, Akuntabilitas Pelanggaran HAM Pada Sektor Bisnis, binus.ac.id (accessed August 12, 2017).

${ }^{6}$ Urgensi Penyusunan Rencana Aksi Nasional Bisnis dan Hak Asasi Manusia di Indonesia, http://elsam.or.id/2015/06/ urgensi-penyusunan-rencana-aksi-nasional-bisnis-dan-hak-asasi-manusia-di-indonesia/ (accessed August 15, 2017).

${ }^{7}$ Rudi M. Rizki, "Tanggung Jawab Korporasi Transnasional dalam Pelanggaran Berat HAM", PJIH Journal, Volume 3 No. 1 of 2016, p. 194.

${ }^{8}$ Harry Octavian, Bisnis dan Hak Asasi Manusia, "Buletin ScaleUp", $2^{\text {nd }}$ edition, 2015, p.1.

${ }^{9}$ Menggugat Kepatuhan HAM Dunia Bisnis, Jakartagresnews.com, (accessed August 16, 2017).
} 
is the problem approach by looking at, examining and interpreting theoretical matters concerning legal principles in the form of conceptions, legislation, views, legal doctrines and related legal systems. This type of approach emphasizes the acquisition of information in the form of legal texts related to the object under study. ${ }^{10}$ This explanatory research aims to describe more clearly and precisely the problems of human rights fulfillment by corporations with several variables such as problems, impacts, and benefits that occur within the community itself. The data used in this research is secondary data obtained through library research by reading, studying literature, legislation, documents related to the issues discussed in this study. The secondary data under study consisted of primary legal materials and secondary legal materials. ${ }^{11}$ Primary legal material is a legislation both nationally and internationally while the secondary legal materials are legal materials in the form of publications about the law that the contents explain and analyze the primary legal materials. Books, articles, draft laws, journals, previous research results are used as secondary legal material in this study.

\section{DISCUSSION}

\subsection{The Development of Responsibility towards Human Rights Fulfillment by Corporation}

\subsection{The Emergence of Business and Human Rights Issues in International Sphere}

The international community's anxiety regarding business practices was preceded by an incident in Nigeria involving Royal Dutch Shell in 1995. Shell is considered to be involved in the execution of Nigerian writer and environmentalist Ken Saro-Wiwa and eight followers. Saro-Wiwa launched a harsh critique of Shell's operations that are considered to have polluted the environment in the Niger River Delta. Saro-Wiwa fought for a fair share of oil wealth and demanded an end to the destruction of Ogoni's land. ${ }^{12}$

Since the incident, international agencies working on human rights issues, such as Human Rights Watch and Amnesty International, are beginning to put business and human rights issues on their agenda. They also increase the pressure on corporate responsibility for negative impacts on the enjoyment of the basic rights of citizens living around the company. The impact of the company's operations on the abolition of human rights has spread in various parts of the world (see table). This situation has prompted the international community to redirect the responsibility of human rights to the non-state actors.

TABLE 1.1

Operations of multinational corporations that negatively impact human rights, particularly the rights of indigenous peoples in various countries ${ }^{13}$

\begin{tabular}{|l|c|l|}
\hline \multicolumn{1}{|c|}{ Company } & Country & \multicolumn{1}{c|}{ Impact } \\
\hline $\begin{array}{l}\text { Ecuador Oil Developments } \\
\text { [Petroequador, } \\
\text { Maxus Oil Co.] }\end{array}$ & Ecuador & $\begin{array}{l}\text { Waorani and other indigenous peoples are } \\
\text { displaced from their lands, biodiversity is lost, water } \\
\text { is exposed to toxins, and environmental damage is } \\
\text { massive due to oil spills. }\end{array}$ \\
\hline $\begin{array}{l}\text { Total, Unocal } \\
\text { [Union Oil Company of } \\
\text { California] }\end{array}$ & Burma & $\begin{array}{l}\text { Involved in violation of labor rights and the use of } \\
\text { slaves. }\end{array}$ \\
\hline Royak Dutch Shell & Nigeria & $\begin{array}{l}\text { Environmental destruction, oppression, seizure of } \\
\text { Ogoni people, arbitrary arrest and detention, and } \\
\text { execution of environmental activists. }\end{array}$ \\
\hline Tanzania Wheat Project & Tanzania & $\begin{array}{l}\text { Forcible transfer, harassment and detention, and } \\
\text { reduced access. }\end{array}$ \\
\hline Borneo Logging [Mitshubishi] & Malaysia & $\begin{array}{l}\text { Forestry and the oppression of the tribe of punan } \\
\text { and other indigenous people }\end{array}$ \\
\hline
\end{tabular}

\footnotetext{
${ }^{10}$ Abdulkadir Muhammad, Hukum dan Penelitian Hukum, (Bandung : Citra aditya bakti, 2004), p.112.

${ }^{11}$ Peter Mahmud Marzuki, Penelitian Hukum, (Jakarta: Kencana, 2008), p.140.

${ }^{12}$ Shell membayarkompensasi korban HAM, http://www.dw.de/shell-membayar-kompensasi-korban-ham/a-4313775, (accessed on August 25, 2017).

${ }^{13} \mathrm{~K}$ Robert Hitchock. 1997. "Indigenous Peoples, Multinational Corporations and Human Rights." Indigenous Affairs, IWGIA, No.2. in Ifdhal Kasim. 2010. " Tanggungjawab Perusahaan terhadap Pemenuhan Hak-hak Ekonomi, Sosial dan Budaya" (paper in National Workshop of Komnas HAM, not published paper), quoted from Asep Mulyana. 2012. "Membangun Corporate Social Rsponsibility (CSR) yang Berperspektif HAM". Paper presented at the Roundtable Discussion of ASEAN Economic Community and Corporate Social Responsibility, organized by Trade Knowledge Network (TKN), International Institute for Sustainable Development (IISD), and Habibie Center. not published paper, p. 3.
} 
IJASOS- International E-Journal of Advances in Social Sciences, Vol. III, Issue 9, December 2017

\begin{tabular}{|l|c|l|}
\hline $\begin{array}{l}\text { Western Desert Mining [Rio } \\
\text { Tinto Zinc]. }\end{array}$ & Australia & $\begin{array}{l}\text { Aborigines are displaced from their traditional } \\
\text { territories, pollution and destruction of resources. }\end{array}$ \\
\hline $\begin{array}{l}\text { Uranium Mining } \\
\text { [Kerr-McGee] }\end{array}$ & New Mexico & $\begin{array}{l}\text { Navajo miners suffer from cancer and other } \\
\text { diseases, but receive minimal compensation and } \\
\text { assistance. }\end{array}$ \\
\hline $\begin{array}{l}\text { Agricultural Project } \\
\text { [SwftArmour, King Ranch] }\end{array}$ & Brazil & $\begin{array}{l}\text { Clearing of forests and the occurrence of social } \\
\text { conflicts. }\end{array}$ \\
\hline
\end{tabular}

Awareness of the importance of corporate responsibility for the impact of human rights increased rapidly in the late 1990s to early 2000. The new initiatives were born, marked by the creation of several business and human rights documents, ${ }^{14}$ including Guiding Principles on Business and Human Rights: Implementing the United Nations "Protect, Respect and Remedy" Framework in 2011 issued by the United Nations Special Representative for Business and Human Rights, John Ruggie (Ruggie Principles).

\subsubsection{The Development of Responsibility towards the Fulfillment of Human Rights by Corporations in INDONESIA}

The old paradigm puts the country in a central position as a duty holder and the individual is placed as a rights holder. In two main human rights norms, the International Covenant on Civil and Political Rights and the International Covenant on Economic, Social and Cultural Rights, the state is responsible for respecting, protecting and fulfilling human rights. Non-state actors, including companies, are not liable stakeholders. As a result, companies cannot be asked for legal responsibility to respect human rights. The new paradigm has emerged since the 1990s when the facts about the presence of companies, especially multinational corporations, in a number of serious human rights violations in the countries where multinational companies operate. Since then the international human rights community has begun to discourse the importance of nonstate actors, in this case the company, being promoted as a duty-bearer in the human rights regime. According to this new paradigm, multinational corporations or other legal bodies outside the country may be legally responsible for human rights abuses they may commit. ${ }^{15}$

Criminally corporations are not originally regarded as legal subjects so that corporations cannot be held responsible for crimes of human rights violations they have committed. This is due to a criminal act is still associated with the physical act performed by actors. Whereas in the modern criminal law literature, it has been reminded that in the field of social economy or in the economy, a criminal offender does not necessarily need to commit the crime physically. Law Number 26 Year 2000 on Human Rights Court also does not recognize the corporation as the subject of offense. Both of these legal instruments only recognize individual criminal responsibility rather than corporate criminal responsibility. The Sub-Commission on Human Rights Promotion and Protection of the United Nations issued a document entitled "Norms on the responsibilities of transnational corporations and other business enterprises with regard to human rights", which states that corporate crime can be defined as a crime committed by corporations covering human rights, humanitarian, labor, crimes against consumer rights and widespread practices of corruption. ${ }^{16}$ This further becomes a reference that criminal law also recognizes human rights violations by corporations as criminal acts. Nevertheless, the inclusion of corporate crime is still regulated partially outside the Criminal Code.

The criminal liability of the corporation is a manifestation of repressive efforts in the fulfillment of human rights, meaning that the action is done after human rights violations committed by the corporation have been proven. In practice it is also uneasy to impose a criminal sanction on the corporation. This responsibility is a different aspect of the Human Rights Due Diligence that is carried out during the running of the company's business activities. But both go hand in hand in the effort to fulfill the human rights of Indonesian citizens.

\subsubsection{The position of the corporation as the duty of fulfillment of human rights}

Corporations come up with the concept that the state is no longer the only organization with the greatest strength. In many aspects, corporations can match the state in terms of role and influence. In fact until now 29 to $51 \%$ of the world's economy is controlled by the corporation with the nature which is able to penetrate the boundaries of the state and able to collect greater resources. ${ }^{17}$ The power of corporations is also capable of influencing democracy, law and even politics so that the function of a country becomes not independent

\footnotetext{
${ }^{14}$ Asep Mulyana. Op. Cit.

${ }^{15}$ Ifdhal Kasim, " Tanggungjawab Perusahaan terhadap Pemenuhan Hak-hak Ekonomi, Sosial dan Budaya", paper in National Workshop of Komnas HAM, not published, 2010.

${ }^{16}$ Patra M. Zein, Kejahatan Korporasi dan Norma tentang Akuntabilitas Korporasi, (Jakarta : YLBHI, 2004$)$, p. 5.

${ }^{17}$ Jonathan Clough, "Punishing The Parent : Corporate Criminal Complicity In Human Rights Abuse", Brooklyn Journal of International Law, 2008, p. 899.
} 
and even lost, especially in the obligation of human rights protection. ${ }^{18}$ The influence of corporations in the policy can be seen in the case of Lapindo mudflow which shows the weakness of the government facing large corporations. In addition to its great strength, business activities by corporations also cause adverse impacts in the society especially in human rights violations. ${ }^{19}$ The table below shows that corporations are one of the institutions that often cause misery in society.

TABLE 1.2

Complaint data received by Indonesian Human Right Counsel between 2012-2015 20

\begin{tabular}{|c|l|c|c|c|c|}
\hline No & Parties Complained & $\mathbf{2 0 1 3}$ & $\mathbf{2 0 1 4}$ & $\mathbf{2 0 1 5}$ & $\mathbf{2 0 1 6}$ \\
\hline 1 & Police & 1.938 & 1.845 & 2.483 & 2.734 \\
\hline 2 & Corporation & 1.126 & 958 & 1.127 & 1.231 \\
\hline 3 & Local Goverment & 569 & 542 & 771 & 1.011 \\
\hline 4 & Institute of Justice & 542 & 484 & 641 & 640 \\
\hline 5 & Central Government & 483 & 488 & 499 & 548 \\
\hline
\end{tabular}

Based on the monitoring and review of Indonesian Human Rights Counsel, human rights most closely related to business activities include the right to a healthy environment, the right to water, the right to life, the right to property and land ownership, the rights of indigenous peoples to communal land and the right to information. ${ }^{21}$ Here are some examples of human rights violations in terms of corporations as perpetrators:

a. PT Newmont Minahasa Raya (NMR) as the main suspect of pollution in Buyat Bay Waters, Kotabunan, Bolang Mongondow Regency of North Sulawesi Province. For 20 years the company conducted gold mining exploration activities there. The disposal of tailings waste (mud waste destruction) of NMR, is suspected to be the cause of pollution.

b. The collapse of the tunnel at PT Freeport Indonesia's Big Gossan underground mine area on May 14, 2013 left 28 people dead and 10 injured. This is due to negligence by PT Freeport Indonesia which allows minimal supervision resulting in accidents. According to Indonesian Human Right Counsel, this incident clearly resulted in the violation of the right to life which is cannot be reduced under any circumstances.

c. Indonesian Environment Forum 2014 research results, states that two large corporations Wilmar and Sinar Mas through its subsidiaries have been doing bad corporate practices. Such actions are land grabs that lead to deforestation and threaten biodiversity. Even the killing of human rights and environmental activists is also one of the crimes committed by Sinar Mas.

d. Eleven civilians in Aceh were victims of human rights violations during the DOM's conflicting period of DOM sued Exxon Mobil contracting Indonesian security forces to secure the productivity of the company. The plaintiffs assessed Exxon Mobil's contract to the TNI had encouraged human rights violations committed by the TNI against residents in Lhokseumawe and around the Arun gas company. 22

Based on the fact above, the corporation would be a threat the stability if that country does not create a control system and appropriate regulation of corporations. ${ }^{23}$ It was initiated by the corporate rights fulfillment by Jimly Asshiddiqie called the fourth generation of human rights. Jimly Asshiddiqie mentions that there are four phenomenal factors that influence the birth of the fourth generation of human rights concepts, ${ }^{24}$ namely: (1) gigantic conglomeration in the form of multinational corporations (MNCs); (2) the phenomenon of stateless nation; (3) global citizen which implicates the birth of separated social class; and (4) setting new autonomous entities in the form of corporate federalism. This is evidence that human rights have a very close relationship with business and corporations which are also responsible for the fulfillment of human rights.

\subsection{Urgency of implementation of Human Right Due Diligence by corporations in Indonesia}

Transnational and local corporations with all their capabilities both in capital, technology, human resources,

\footnotetext{
${ }^{18}$ Lubis Santosa Maramis, Corporate Responsilibility, http: //lsmlaw.co.id/, (accessed August 11, 2017).

${ }^{19}$ Ahmad Sofian, Pertanggungjawaban Pidana Korporasi dalam Delik HAM, (Jakarta : Bina Nusantara, 2015$)$, p .1.

${ }^{20}$ Aliansi Jurnalis Independen, Jurnalis Mendalami Kewajiban Sektor Bisnis Menghormati Hak Asasi Manusia, https://aji.or.id/read/berita/578/jurnalis-mendalami-kewajiban-sektor-bisnis-menghormati-hak-asasi-manusia.html (accessed August 11, 2017).

${ }^{21}$ Patricia Rinwigati, Business and Human Rights in ASEAN : A Baseline Study, (HRRCA : 2013), p. 96.

${ }^{22}$ Kontras, "Perjuangan Korban DOM Aceh Menuntut Keadilan di Pengadilan USA", Briefing Paper, p. 1.

${ }^{23}$ Koesparmono Irsan and Nian Syaifudin, Kejahatan Korporasi, (Jakarta : STIK, 2011), p. 25.

${ }^{24}$ Jimly Asshiddiqie, Hukum Tata Negara dan Pilar-Pilar Demokrasi, (Jakarta : PT BIP, 2007), p. 222.
} 
network and ability to influence government have mastered the natural resources that affect the livelihood of many people. ${ }^{25}$ With these advantages are expected in the practice of operation, corporations still uphold the fulfillment of human rights. In order to ensure the fulfillment of human rights by a corporation a process is used to ensure that in the conduct of its business and operations, a cooperative is concerned with the human rights aspect. This is called human rights due diligence. ${ }^{26}$

Human rights due diligence is a process that identifies the potential risks of human rights violations related to business operations and takes effective measures to prevent and mitigate its negative impacts. Corporation is also responsible for ensuring that victims of any violations are able to reach the recovery process. ${ }^{27}$ This process is different from the corporate crime that has been discussed in the previous chapter because human rights due diligence is a preventive and recovery process of the victims. It also has a different meaning with Corporate Social Responsibility in the form of giving benefit to the community voluntarily to improve the quality of life and a useful environment.

\subsubsection{Background to the Formation of Human Rights Due Diligence}

In 1998, a subsidiary body of the Commission on Human Rights drafted the norm for human rights and business. The proposal of the subcommittee was published in 2003 with the official title "Norms regarding the responsibility of transnational corporations and other companies with respect to Human Rights" or later known as "The Design of Norms". ${ }^{28}$ This draft norm raises the debate of all parties. Human rights advocacy groups are very supportive of this on the other hand the business group is strongly against it. After the debate, the Commission on Human Rights felt it was necessary to continue the discussion and propose the Secretary-General of the United Nations to appoint a Special Representative to try to bring the parties together and see the latest approaches.

John Ruggie, a Harvard professor who was appointed as the "Special Representative of the SecretaryGeneral of the United Nations for Human Rights and Transnational Corporations and Other Business Companies" tasked with investigating the specific situation of business and human rights and having the obligation to report to the Human Rights Council every year. The debate between business and human rights reached its peak in 2011 when the UN Human Rights Commission unanimously and legally endorsed Guiding Principles for Business and Human Rights: Implementing the United Nations Framework "Protection, Reconciliation and Recovery."

This endorsement took place after John Ruggie completed and produced a global standard for business and human rights with the great support of all UN member states without going through the voting process in the sense that the guiding principles were universally supported. This endorsement also becomes history in sixty years of the United Nations with unanimous decisions. This principle is called the United Nations Guiding Principles on Business and Human Rights, Implementing the United Nations "Protect, Respect, and Remedy" Framework (UNGP) by the name of Ruggie's Principles. ${ }^{29}$

UNGP underlies the guiding principles for business and human rights with the three pillars namely protect, respect, and remedy of human rights as follows: ${ }^{30}$

a. The responsibility of the state to protect human rights from violation by a third party, including the company, through appropriate policies, arrangements, and decisions. The state retains a major role in preventing human rights violations;

b. The responsibility of the corporation to respect human rights requires a serious action to avoid human rights violations by other parties and to resolve the negative impacts of the corporation's work. The

\footnotetext{
${ }^{25}$ Nur Kholis, Tanggung Jawab Negara dan Tanggung Jawab Sosial Korporasi, http://referensi.elsam.or.id/, (accessed August 27, 2017). This material is presented in the Human Rights Course held by Indonesian Human Right Counsel and Indonesian Environment Forum in Bogor, January 16, 2015.

${ }^{26}$ See Rahayuningsih Hoed, “Legal Due Diligence: Special Education Material Advocate Profession”, (Jakarta: Lembaga Pendidikan Hukum, 2005), p. 1, in Law Review Journal, Faculty of Law of Pelita Harapan University, Volume V, Number 2, November 2005.

${ }^{27}$ Human Right Watch, Panen dengan Darah Kami : Bahaya Pekerja Anak dalam Perkebunan Tembakau di Indonesia, (Amerika Serikat : Human Rights Watch, 2016), p. 22.

${ }_{28}$ Harry Octavian, "Bisnis dan Hak Asasi Manusia (Hak Asasi Manusia)", Jurnal Scale Up, Edisi II-2015, p. 1.

${ }^{29}$ Business \& Human Rights Initiative, How To Do Business With Respect For Human Rights: A Guidance Tool For Companies, "The Hague Global Compact Network Netherlands", 2010, p. 21-22, in Muhamad Raziv Barokah, Formulasii Adopsi United Nations Guiding Principle on Business And Human Rights Dalam Good Corporate Governance oleh Perseroan Terbatas di Indonesia, (Thesis on Shariah and Law Faculty of Syarif Hidayatullah State Islamic University, 2015), p.3.

30 John Ruggie, Guiding Principles on Business and Human Rights: Implementing the United Nations "Protect, Respect and Remedy Framework", not published, 2011.
} 
corporation is required to have a statement of commitment to respect human rights, to assess human rights impacts, and to integrate human rights principles into internal processes, functions and policies;

c. Broad access for victims of human rights violations to obtain effective recovery schemes, judicially and non-judicially. An effective complaints mechanism within a corporation should be provided as a mechanism for respecting human rights. States should take steps in their jurisdiction to ensure that victims have access to effective remedies through judicial, administrative, or legislative.

Based on these three pillars, the corporation should internalize these guiding principles into its business operations. This is because these guiding principles have set the standard for corporations on how they should respect and protect the prevailing human rights in a country in which the corporation operates. These principles are also a means of avoiding or reducing the impact of human rights that reduce risks to corporations. Therefore, in order to comply with and implement the guiding principles, corporations must integrate human rights in the operationalization of their business by conducting human rights due diligence.

\subsubsection{Legal Basis of Human Right Due Diligence in Indonesia}

To be able to apply UNGP in Indonesia it must be seen the legal basis of its validity. UNGP is basically nonbinding. Human Rights Watch states that UNGP will only apply if the state and the corporation are willing to apply it, and will not apply if the wish does not exist. UNGP is a resolutions applicable to a country if the country declares itself to support the resolution and takes concrete action by adopting the resolution into national legal system and not through ratification. Indonesia has proclaimed itself to support UNGP through its national business and human rights symposium but the principle has not yet been implemented in the form of legislation so it has not been effective. This is seen in Presidential Regulation No. 75 of 2015 on the National Plan of Action on Human Rights 2015-2019 which has not set the dimensions of corporate responsibility to respect human rights.

Although not effective yet in the legal system of Indonesia, partially human rights due diligence has been applied in business activities in the fishery sector in Indonesia. In celebration of International Human Rights Day December 2015, the Minister of Marine Affairs and Fisheries, Susi Pudjiastuti announced the enactment of Regulation of the Minister of Marine Affairs and Fisheries No. 35 of 2015 on Fisheries Rights System and Certification (Permen KP HAM Perikanan). Permen KP HAM Perikanan as a general provision the human rights regulation in the fishery field contains three main provisions. First, human rights standards that refer to UNGP principles. Second, due diligence to business actors to meet human rights standards. Third, the restoration of human rights or the reparation of victims from human rights violations. ${ }^{31}$

In such a regulation, human rights due diligence is defined as a process undertaken by the Fisheries Entrepreneur to identify, assess, prevent, mitigate, and address the impact of human rights violations arising from the activities, operations and business relations of the Fisheries Entrepreneur. ${ }^{32}$ Implementation of human rights due diligence carried out by Human Rights Team whose duty is to grant, reject, suspend and revoke fishery human rights certificate to Fishery Entrepreneur. ${ }^{33}$ Each of fishery shall be equipped with a certificate of human rights in conducting their business activities obtained through the implementation of human rights due diligence. Without the certificate, fishery entrepreneurs will get sanction in the form of postponement of business permit, revocation of business license, recommendation of revocation of work permit to the Ministry of Labour. ${ }^{34}$

UNGP mandates countries wishing to adopt these principles to create a National Plan of Action on Business and Human Rights. Indonesia has created a National Business and Human Rights Action Plan which was launched on 16 June 2017. However, in order to have the legal power of the National Action Plan, it is necessary to be regulated further in a legislative regulation such as a presidential regulation.

\footnotetext{
31 Perusahaan Wajib Punya Sertifikat HAM, http://koran.bisnis.com/read/20160816/452/57 5550/perusa haan-wajibpunya-sertifikat-ham, (accessed August 20, 2017). Regulation of the Minister of Marine Affairs and Fisheries no. 35/2015 on the System and Certification of Human Rights on Fishery Enterprises has stipulated that the Task Force to Combat Illegal Fish Catching is required to have a Human Rights certificate.

${ }^{32}$ Republic of Indonesia, Article 1 point 14 Regulation of the Minister of Marine Affairs and Fisheries No. 35 of 2015 on Sistem dan Sertifikasi HAM Perikanan.

${ }^{33}$ Republic of Indonesia, Article 9 paragraph (4) letter c of the Minister of Marine Affairs and Fisheries Regulation No. 35 of 2015 on Sistem dan Sertifikasi HAM Perikanan.

${ }^{34}$ Republic of Indonesia, Article 8 and Article 12 of the Regulation of the Minister of Marine Affairs and Fisheries No. 35 of 2015 on Sistem dan Sertifikasi HAM Perikanan.
} 
IJASOS- International E-Journal of Advances in Social Sciences, Vol. III, Issue 9, December 2017

\subsubsection{Mechanisms and Benefits of Implementation of Human Right Due Diligence in business activities}

According to UNGP, human rights due diligence is an sustainable process of the company to examine the impact of human rights on its operations, to act on the basis of the study and to communicate the treatment. ${ }^{35}$ The main components studied are the actual or potential impact of human rights violations from a business operation. Companies may use independent human rights experts to conduct assessments. The expert will then consult with the affected groups. If human rights violations are found then the state should ensure access to recovery for affected groups. The recovery mechanism can be a mechanism of judicial mechanisms, non-judicial complaints mechanisms and non-state complaints mechanisms. Industry, stakeholders and joint initiatives should ensure that effective complaints mechanisms are available. ${ }^{36}$

To conduct a comprehensive human rights due diligence, the corporation should make technical efforts such as: ${ }^{37}$

a. Identify and assess the undesirable impact of a business activity;

b. Integrate findings of impact assessment into relevant internal processes and functions and take appropriate action;

c. Traces the effectiveness of a company's response in an effort to verify whether undesirable impacts have been addressed, using quantitative and qualitative indicators and using feedback from internal and external sources including affected stakeholders;

d. Communicating the company's efforts on handling the impact of business activities on human rights to outsiders in a format and frequency reflecting those impacts, and accessible to the intended audience.

In general, the corporation has 3 aspects in the implementation of human rights, namely to prevent involvement of human rights violations, due diligence, and mechanisms of complaints at the internal level. The fact that the implementation of Corporate Social Responsibility is not sufficient in providing benefits to the community, corporations are also required to comply with human rights values and norms ${ }^{38}$ through human rights due diligence. The process of human rights due diligence aims to identify, prevent, mitigate and account for how companies deal with the impact of Human Rights. ${ }^{39}$ Implementation of human rights due diligence is not only beneficial to employers but also society as a whole. For entrepreneurs, business competition created not only about capital and facilities, but also about the level of compliance with human rights. Especially for the community, the implementation of human rights due diligence will provide many advantages, including the realization of a business field that is friendly environment and worker.

The human rights due diligence regime will deliver the reputation of the company based not only on CSR, capital and profit, but also on corporate compliance with human rights. A study conducted by Global CSR Study 2013 states that consumers are more believe at companies that have a positive effect on solving social and environmental problems than companies that only want to seek profit for their shareholders. It is also mentioned by Marzuki, director of Human Rights Research Center for ASEAN, that a good level of human rights compliance will also be an attraction for investors. In the end this will have a positive impact on the reputation of a corporation.

\section{CONCLUSION}

Based on the exposure that has been described above, the conclusion of this study are:

a. Corporations were originally known only in civil law. However, in the development of the SubCommission on the Promotion and Protection of Human Rights of the United Nations, it issued Norms on the responsibilities of transnational corporations and other business enterprises with regard to human rights which can simply be defined as corporate crimes covering human rights, labor, crimes against consumer rights and the widespread practice of corruption. This becomes a reference that the

\footnotetext{
${ }^{35}$ NHRC, Guiding Principles on Business and Human Rights, Implementing the United Nations "Protect, Respect, and Remedy" Framework, not published, 2011.

${ }^{36}$ This was conveyed by John Ruggie, who created the United Nations Guiding Principles for Business and Human Rights in 2011 through an extensive 6-year process and professor of human rights and international affairs at the Kennedy School of Government, Cambridge in a discussion on business and human rights at the Crowne Plaza hotel, South Jakarta, February 2014.

${ }^{37}$ Principles of Business and Children, Unicef Brief, p. 7-8, see also UNHRC, Guiding Principles on Business and Human Rights, Implementing the United Nation "Protect, Respect, and Remedy" Framework, not published, 2011.

${ }^{38}$ Kepatuhan HAM Tentukan Reputasi Korporasi, http://jakarta.kemenkumham.go.id/berita-hukum-dan-ham/352kepatuhan-ham-tentukan-reputasi-korporasi-, (accessed August 20, 2017).

${ }^{39}$ Kode Bettercoal, 1st version 27Juny 2013 (Adopted by Bettercoal Members on November 12, 2016), http://bettercoal.org/docs/Bettercoal-Code-Version-1-Final-Bahasa.pdf.
} 
criminal law also recognizes the actions of the corporation as a criminal act, including in the case of human rights violations. Especially after the incident in Nigeria involving Royal Dutch Shell in 1995 which is considered to have polluted the environment in the Delta River Niger. International agencies working on human rights issues, such as Human Rights Watch and Amnesty International, are beginning to put business and human rights issues on the agenda. Through this incident, the fulfillment of human rights in the world is not only imposed on the state but also on individuals and corporations.

b. International attention to business and human rights began when the UN through its representative John Ruggie issued the United Nations Guiding Principles on Business and Human Rights Principles (UNGP), also known as Ruggie's Principles. One of the implementation of this principle is the implementation of human rights due diligence. Human rights due diligence is a process that identifies the potential risks of human rights violations related to business operations and takes effective measures to prevent and mitigate its negative impacts. The corporation is also responsible for ensuring that victims of any violations are able to reach the recovery process. This process is very different from corporate crime because in fact human rights due diligence is a process that is preventive and covers the recovery process of the victims not as a repressive effort for a human rights violation by the corporation. Implementation of human rights due diligence becomes very important to do given the very strong corporate position in influencing the policy and the court.

\section{ACKNOWLEDGEMENT}

With the completion of writing this paper, the author would like to thank to Indonesia Endowment Fund for Education (Lembaga Pengelola Dana Pendidikan) that supports the funding of this reseacrh, University of Indonesia as an institution where the author studied, The reviewers who have provided critiques and suggestions regarding the writing of this paper and all parties who have supported the author.

\section{REFERENCE LIST}

\section{- Legislation}

Constitution of Indonesia.

Law No. 26 of 2000 on the human rights court.

Law No. 39 of 1999 on Human Rights.

Law No. 23 of 1997 on Environmental Management.

Regulation of the Minister of Marine Affairs and Fisheries No. 35 of 2015 on Sistem dan Sertifikasi HAM Perikanan.

\section{- Books}

Abdulkadir Muhammad (2004), Hukum dan Penelitian Hukum, Bandung, Citra aditya bakti.

Ahmad Sofian (2015), Pertanggungjawaban Pidana Korporasi dalam Delik HAM, Jakarta, Bina Nusantara.

Iman Prihandono (2015), Kerangka Tiga Pilar Bisnis \& HAM: Uji Tuntas HAM, Surabaya, Universitas Airlangga.

Jimly Asshiddiqie (2007), Hukum Tata Negara dan Pilar-Pilar Demokrasi, Jakarta, PT BIP.

Koesparmono Irsan and Nian Syaifudin (2011), Kejahatan Korporasi, Jakarta, STIK.

Patra M. Zein (2004), Kejahatan Korporasi dan Norma tentang Akuntabilitas Korporasi, Jakarta, YLBHI.

Patricia Rinwigati (2013), Business and Human Rights in ASEAN : A Baseline Study, HRRCA.

Peter Mahmud Marzuki (2008), Penelitian Hukum, Jakarta, Kencana.

Saafroedin Bahar (2002), Context State Human Rights , Jakarta, Pustaka Sinar Harapan.

See Rahayuningsih Hoed (2005), Legal Due Diligence: Special Education Material Advocate Profession, Jakarta: Lembaga Pendidikan Hukum

William R. Slomanson (2000), Fundamental Perspectives on International Law, Belmont, Wadsworth.

\section{- Paper, Brief and Journal}


Asep Mulyana (2012), Membangun Corporate Social Rsponsibility (CSR) yang Berperspektif HAM, Paper presented at the Roundtable Discussion of ASEAN Economic Community and Corporate Social Responsibility, organized by Trade Knowledge Network (TKN), International Institute for Sustainable Development (IISD), and Habibie Center, not published.

Harry Octavian (2015), Bisnis dan Hak Asasi Manusia, Buletin ScaleUp, vol. 2.

Human Right Watch (2016), Panen dengan Darah Kami : Bahaya Pekerja Anak dalam Perkebunan Tembakau di Indonesia, Amerika Serikat, Human Rights Watch.

Ifdhal Kasim (2010), Tanggungjawab Perusahaan terhadap Pemenuhan Hak-hak Ekonomi, Sosial dan Budaya, paper presented in National Workshop of Komnas HAM, not published.

John Ruggie (2011), Guiding Principles on Business and Human Rights: Implementing the United Nations "Protect, Respect and Remedy Framework", not published.

Jonathan Clough (2008), Punishing The Parent : Corporate Criminal Complicity In Human Rights Abuse, Brooklyn Journal of International Law.

K Robert Hitchock (1997), Indigenous Peoples, Multinational Corporations and Human Rights, Indigenous Affairs, IWGIA, No.2.

Kontras, Perjuangan Korban DOM Aceh Menuntut Keadilan di Pengadilan USA, Briefing Paper.

Muhamad Raziv Barokah (2015), Formulasi Adopsi United Nations Guiding Principle on Business And Human Rights Dalam Good Corporate Governance oleh Perseroan Terbatas di Indonesia, Thesis on Shariah and Law Faculty of Syarif Hidayatullah State Islamic University.

NHRC (2011),Guiding Principles on Business and Human Rights, Implementing the United Nations "Protect, Respect, and Remedy" Framework, not published.

Nur Kholis (2015), Tanggung Jawab Negara dan Tanggung Jawab Sosial Korporasi, , paper presented in the Human Rights Course held by Indonesian Human Right Counsel and Indonesian Environment Forum in Bogor.

Rights Resources Initiative (2015), Space-Space Case Advocacy Respect for Human Rights by the Company, Batam, ASM Law Office.

Rudi M. Rizki (2016), Tanggung Jawab Korporasi Transnasional dalam Pelanggaran Berat HAM, PJIH Journal, vol. 3 no. 1.

\section{- Internet}

Ahmad Sofian, Akuntabilitas Pelanggaran HAM Pada Sektor Bisnis, binus.ac.id.

Aliansi Jurnalis Independen, Jurnalis Mendalami Kewajiban Sektor Bisnis Menghormati Hak Asasi Manusia, https://aji.or.id/read/berita/578/jurnalis-mendalami-kewajiban-sektor-bisnis-menghormati-hak-asasimanusia.html .

Kepatuhan HAM Tentukan Reputasi Korporasi, http://jakarta.kemenkumham.go.id/berita-hukum-danham/352-kepatuhan-ham-tentukan-reputasi-korporasi-.

Kode Bettercoal, 1st version 27Juny 2013 (Adopted by Bettercoal Members on November 12, 2016), http://bettercoal.org/docs/Bettercoal-Code-Version-1-Final-Bahasa.pdf.

Lubis Santosa Maramis, Corporate Responsilibility, http: //lsmlaw.co.id.

Menggugat Kepatuhan HAM Dunia Bisnis, Jakartagresnews.com.

Perusahaan Wajib Punya Sertifikat HAM, http://koran.bisnis.com/read/20160816/452/57 5550/perusa haanwajib-punya-sertifikat-ham.

Shell membayarkompensasi korban HAM, http://www.dw.de/shell-membayar-kompensasi-korban-ham/a$\underline{4313775}$.

Urgensi Penyusunan Rencana Aksi Nasional Bisnis dan Hak Asasi Manusia di Indonesia, http://elsam.or.id/2015/06/urgensi-penyusunan-rencana-aksi-nasional-bisnis-dan-hak-asasi-manusiadi- indonesia. 